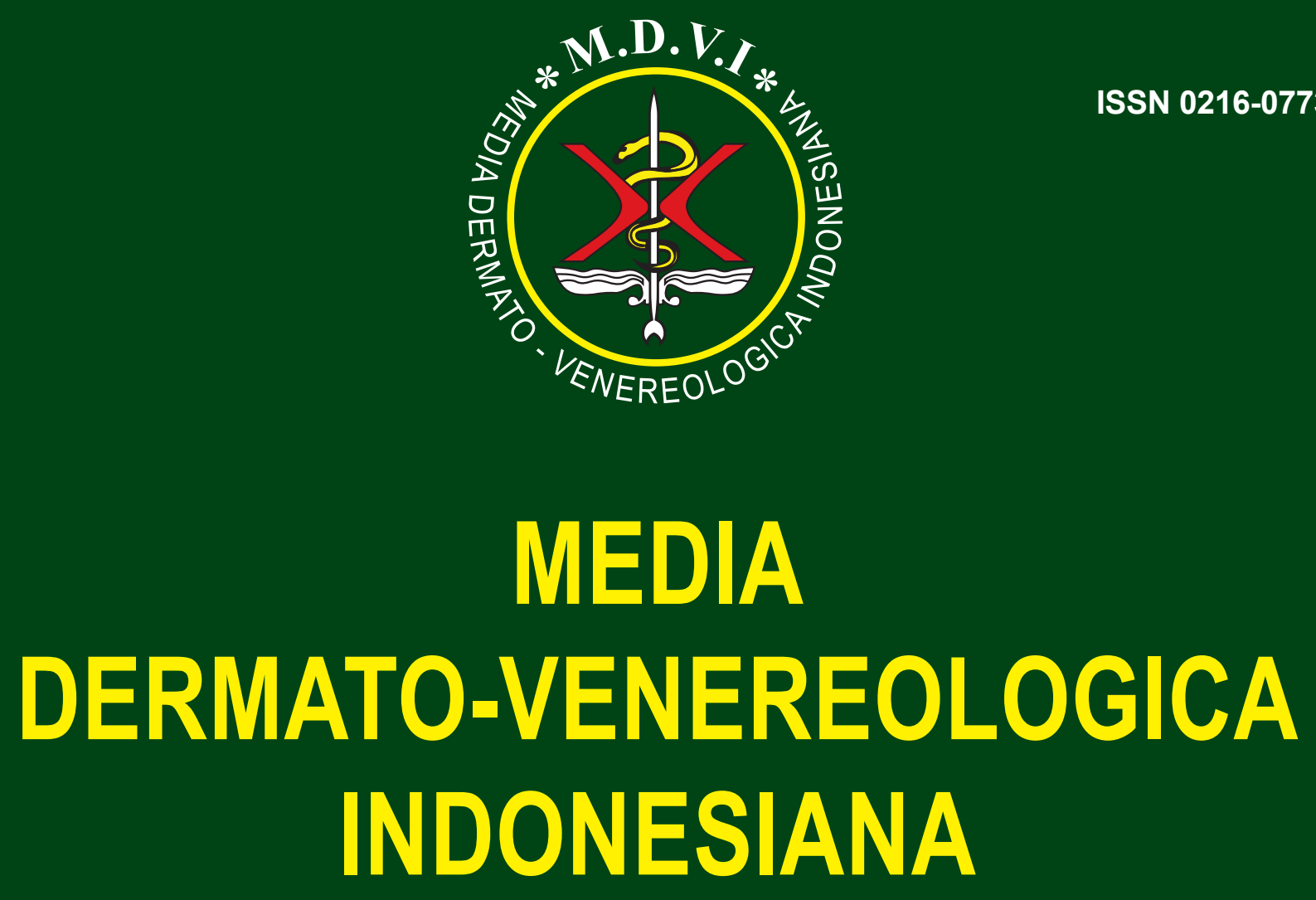

Editorial : Trias epidemiologis : Pendekatan memahami orkestra sistem imunologi kulit

Uji klinis sampo formulasi khusus pada pasien ketombe dan dermatitis seboroik ringan pada skalp

Tingkat pengetahuan dan sikap pekerja binatu terhadap dermatitis kontak

Korelasi antara kadar superoksida dismutase dengan malondialdehid pada jaringan keratosis seboroik

Psoriasis vulgaris berat diterapi mikofenolat mofetil: tantangan dalam pengobatan

Terapi dapson pada pemfigoid bulosa

Modern wound dressing pada ulkus trofik pasien kusta tipe lepromatosa

Peningkatan enzim transaminase pada kusta

Korelasi gambaran histopatologi, teknik biopsi dan manifestasi klinis vaskulitis leukositoklastik kutan

Peran mikrobiom pada infeksi menular seksual

Melasma dalam sudut pandang genetik 


\title{
MODERN WOUND DRESSING PADA ULKUS TROFIK PASIEN KUSTA TIPE LEPROMATOSA
}

\author{
Rio Yansen Cikutra, ${ }^{*}$ Fitra Hergyana, ${ }^{* *}$ Gilang Mayasari ${ }^{*}$ \\ "Dokter Internship, RSUD Karawang, Karawang \\ ${ }^{* *}$ Departemen Kulit dan Kelamin, RSUD Karawang, Karawang
}

\begin{abstract}
ABSTRAK
Ulkus trofik merupakan salah satu bentuk deformitas kaki yang sering ditemukan pada pasien kusta dan dapat menyebabkan disabilitas pada sekitar 10\% - 20\% pasien kusta. Salah satu terapi ulkus trofik adalah menggunakan hydrocolloid dressing, yang merupakan modern wound dressing untuk merangsang penyembuhan dengan menyediakan lingkungan yang lembap dalam proses penyembuhan luka dan melindungi permukaan luka dari trauma atau kontaminasi bakteri. Dilaporkan sebuah kasus ulkus trofik pada seorang perempuan berusia 61 tahun dengan kusta tipe lepromatosa. Diagnosis ulkus trofik ditegakkan berdasarkan gejala klinis berupa beberapa ulkus di telapak kaki disertai anestesi dengan dasar jaringan granulasi, timbul sejak empat tahun yang lalu. Ulkus berbentuk oval dan berukuran $4 \mathrm{~cm} \times 5 \mathrm{~cm} \times 1,5 \mathrm{~cm}$. Pasien diterapi dengan hidrokoloid yang diaplikasikan pada luka dan diganti setiap 3 hari sekali. Perbaikan ulkus trofik pada kasus ini mulai tampak pada hari ke-28 berupa ulkus semakin dangkal dan mengecil. Pada pengamatan hari ke-70, ulkus menutup menjadi sikatriks eutrofik. Berdasarkan laporan kasus ini, penggunaan hidrokoloid merupakan pilihan terapi yang efektif bila digunakan pada jenis luka yang tepat dan dipantau secara rutin.
\end{abstract}

Kata kunci: ulkus trofik, kusta, hidrokoloid

\section{MODERN WOUND DRESSING FOR TROPHIC ULCER IN LEPROMATOUS LEPROSY PATIENT}

\begin{abstract}
Trophic ulcer is a form of foot deformity that is often found in leprosy patients and may cause disability in 10-20\% of cases. One of the therapies used in trophic ulcer is hydrocolloid dressing, a modern wound dressing that stimulates healing by providing a moist environment for wound and protecting the wound surface from bacterial contamination or trauma. A case of trophic ulcer in a 61-year-old woman with lepromatous leprosy was reported. The diagnosis of trophic ulcer is established based on clinical symptoms of an anesthetic ulcer on the sole with the basis of granulation tissue that have appeared for four years. The ulcer's shape is oval with a size of $4 \mathrm{~cm} \times 5 \mathrm{~cm} \times 1.5 \mathrm{~cm}$. The patient was treated with hydrocolloid application to the ulcer every three days. The improvement of trophic ulcer in this case was seen on the $28^{\text {th }}$ day as the ulcer has became shallower and smaller. On the $70^{\text {th }}$ day, the ulcer healed into an eutrophic cicatrix. Based on this case report, the use of hydrocolloid is an effective choice of treatment when used on the right type of wound and with routine monitoring.
\end{abstract}

Keywords: trophic ulcer, leprosy, hydrocolloid

Korespondensi:

Jl. Galuh Mas Raya No.1, Karawang

Telp: 0267-640444

Email: rio.yansen9408@gmail.com 


\section{PENDAHULUAN}

Ulkus trofik yang berasal dari bahasa Yunani yaitu "trophe" yang berarti nutrisi adalah ulkus yang disebabkan oleh berbagai macam faktor misalnya gangguan nutrisi pada jaringan, insufisiensi vaskular, atau kerusakan fungsi saraf. ${ }^{1,2}$ Ulkus jenis ini umumnya terjadi pada kaki pasien diabetes atau kusta. ${ }^{1}$ Ulkus trofik merupakan salah satu bentuk deformitas kaki yang sering ditemukan pada pasien kusta ${ }^{3,4}$ dan dapat menyebabkan disabilitas pada sekitar 10\% - 20\% pasien kusta. $^{5}$

Salah satu cara pengobatan ulkus trofik adalah dengan menggunakan dressing. ${ }^{1,5}$ Wound dressing adalah cara pengobatan luka menggunakan bahan yang diaplikasikan pada luka untuk menstimulasi penyembuhan dengan menciptakan lingkungan yang lembap pada luka dan juga melindungi permukaan luka dari trauma atau kontaminasi bakteri. ${ }^{6,7}$ Banyak pilihan dari jenis modern wound dressing, antara lain berbahan alginat, hidrogel, hidrofiber, dan hidrokoloid. ${ }^{5,6,8,9}$

Hidrokoloid tersusun atau bahan elastometrik (polyurethane) yang bersifat adhesif dan koloid. ${ }^{6,7}$ Bahan dasar koloid yang sering digunakan adalah carboxymethyl cellulose (CMC), pektin, dan gelatin. ${ }^{6}$ Sifat bahan dasar ini tidak dapat ditembus oleh bakteri atau bahan kontaminan lain. ${ }^{7}$ Berdasarkan beberapa hasil penelitian diketahui bahwa penggunaan hidrokoloid lebih unggul daripada pilihan terapi lain pada ulkus di daerah tungkai atau kaki, karena selain dapat mempercepat dan menyembuhkan luka secara total. ${ }^{7,10}$

Berikut ini dilaporkan satu kasus ulkus trofik yang membaik setelah dilakukan terapi hidrokoloid wound dressing pada seorang perempuan berusia 61 tahun dengan kusta tipe lepromatosa polar (LL) yang sudah diderita selama empat tahun dan tidak membaik dengan perawatan luka biasa.

\section{KASUS}

Seorang perempuan berusia 61 tahun datang ke poliklinik kulit dan kelamin dengan keluhan luka borok terbuka di telapak kaki kanan yang mati rasa sejak empat tahun yang lalu. Awalnya luka berupa bisul yang kemudian pecah dan menimbulkan luka yang bertambah besar sampai seukuran uang logam lima ratus rupiah. Pasien sempat berobat untuk luka tersebut selama tiga bulan di puskesmas, namun tidak kontrol sehingga luka tetap terbuka. Pasien pernah didiagnosis kusta dan berobat ke puskesmas kurang lebih 8 tahun yang lalu, pada saat itu timbul bercak merah di lengan, tubuh dan wajah. Bercak terasa baal, tidak ada gatal dan nyeri. Pasien menjalani pengobatan hingga tuntas selama dua tahun.

Pada keluarga tidak terdapat anggota keluarga yang menderita penyakit serupa. Terdapat riwayat kontak dengan teman yang menderita kusta 35 tahun yang lalu. Tidak ada riwayat alergi baik obat maupun makanan. Tidak ditemukan penyakit penyerta.

Pasien baru pertama kali mengalami luka seperti ini. Riwayat kerontokan rambut, alis, atau bulu mata disangkal.
Pasien juga tidak mengalami adanya gangguan penglihatan, kesulitan menutup mata dengan sempurna, perubahan bentuk hidung, hidung tersumbat, mimisan, suara sengau, perubahan bentuk wajah, dada membesar. Namun, pasien mengeluhkan tangan dan kaki yang terasa baal disertai jari-jari tangan dan kaki yang memendek. Riwayat sering haus, sering buang air kecil, dan sering lapar disangkal.

Pada pemeriksaan fisik didapatkan tekanan darah 110/70 $\mathrm{mmHg}$, nadi $86 \mathrm{x} / \mathrm{menit}$, pernapasan $18 \mathrm{x} / \mathrm{menit}$ dan suhu aksila $36,6^{\circ} \mathrm{C}$.

Pada pemeriksaan dermatologik, wajah, dada, dan punggung tampak lesi makula eritematosa, bentuk tidak teratur, multipel, diskret ukuran terkecil $2 \mathrm{~cm} \times 3 \mathrm{~cm}$ dan terbesar $4 \mathrm{~cm}$ $\mathrm{x} 5 \mathrm{~cm}$, batas tegas, tidak menimbul, kering. Pada regio plantar pedis dekstra terdapat ulkus dengan dasar jaringan granulasi, berbentuk oval dan ukuran $4 \mathrm{~cm}$ x $5 \mathrm{~cm}$ x1,5 cm (gambar 1). Pada pemeriksaan sensibilitas tidak didapatkan nyeri pada ulkus disertai gloves and stocking anesthesia.

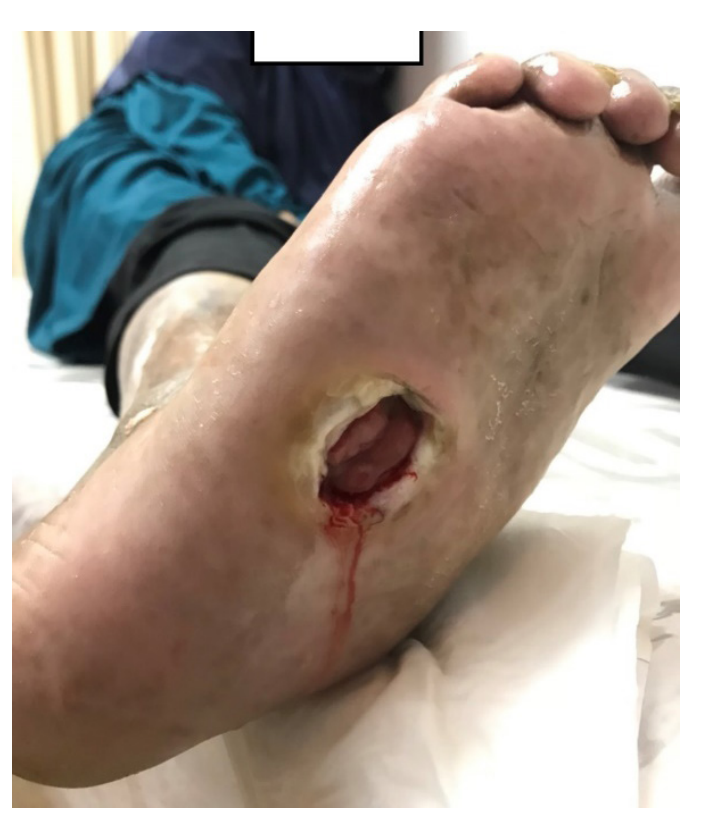

Gambar 1. Ulkus trofik dengan dasar jaringan granulasi, berbentuk oval dan berukuran $4 \mathrm{~cm}$ x $5 \mathrm{~cm}$ x1,5 cm

Diagnosis pada pasien adalah kusta tipe Lepromatosa disertai gloves and stocking anesthesia dan ulkus trofik pedis dekstra. Terapi ulkus trofik pada pasien ini ialah hidrokoloid yang diaplikasikan pada luka dan diganti setiap tiga hari sekali. Perbaikan ulkus trofik pada kasus ini mulai tampak pada hari ke-28 (gambar 2) berupa ulkus semakin dangkal dan mengecil. Pada pengamatan hari ke-70, ulkus sembuh, menutup menjadi sikatriks eutrofik. (gambar 3). 


\section{PEMBAHASAN}

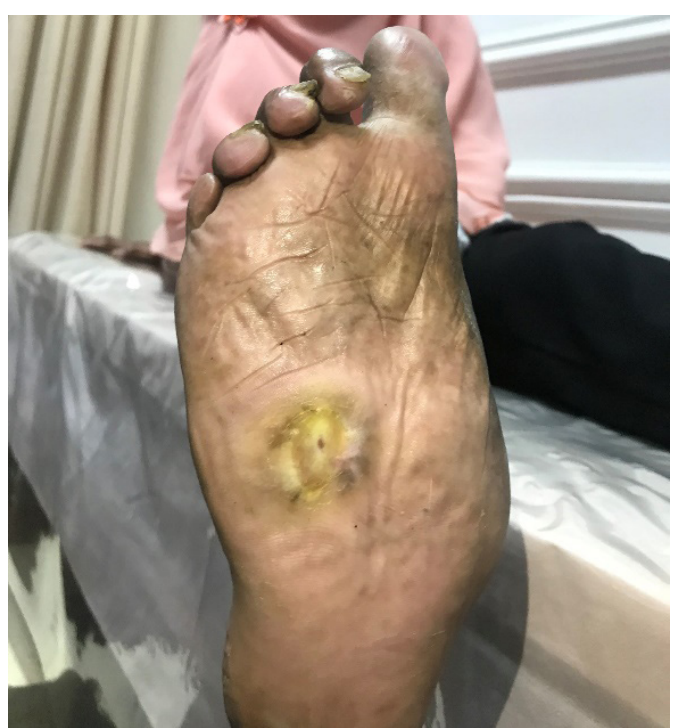

Gambar 2. Pengamatan pada hari ke-28

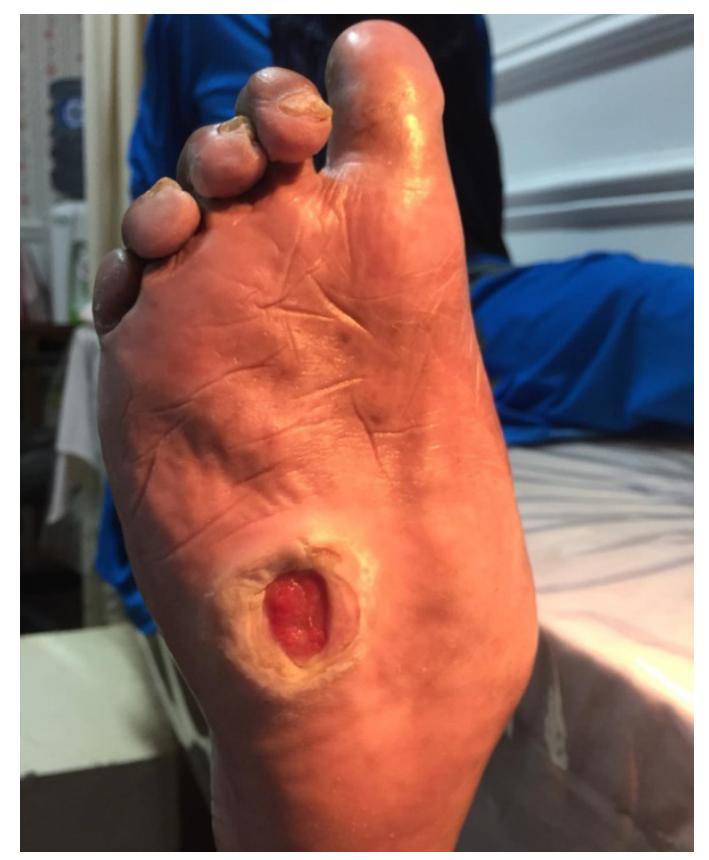

Gambar 3. Pengamatan hari ke-70

Ulkus trofik atau sering disebut juga sebagai ulkus plantaris, ${ }^{11}$ menunjukkan ciri khas berupa hilangnya jaringan di bagian permukaan tubuh yang mengalami anestesi dan berkurangnya aliran darah. ${ }^{12}$ Predileksi ulkus trofik kaki umumnya terdapat di bagian phalang proximal ibu jari kaki. ${ }^{5}$ Ulkus ini cenderung mengalami kekambuhan meskipun sudah diobati. $^{5}$

Pada pasien kusta, ulkus trofik merupakan komplikasi pada kaki yang sering terjadi dan dapat menyebabkan disabilitas. ${ }^{3-5}$
Kaki pasien kusta sering mengalami anestesi, sehingga pasien tidak menyadari rasa nyeri ataupun trauma. ${ }^{3}$ Ulkus trofik dapat terjadi pada kusta tipe pausibasilar (PB) maupun tipe multibasilar (MB). ${ }^{12}$

Penyebab ulkus trofik umumnya akibat trauma dari luar pada kaki yang anestesi, ${ }^{1}$ kemudian menimbulkan bula pada kulit, selanjutnya menjadi luka terbuka. Faktor lain yang dapat menyebabkan ulkus trofik adalah gangguan neurogenik misalnya pada neuropati diabetikum, spina bifida, alcoholic polyneuropathy, gangguan vaskular baik pada arteri misalnya peripheral vascular disease, arteriosklerosis, mikroangiopati pada diabetes, maupun pada vena misalnya venous statis ulcer. ${ }^{1,5}$ Gangguan sistemik atau kondisi malnutrisi juga dapat menyebabkan timbulnya ulkus trofik misalnya pada keadaan defisiensi vitamin B12, avitaminosis berat atau ulkus akibat deposit dari gout. ${ }^{1,5}$

Pada kasus ini, ulkus trofik terdapat di bagian tengah telapak kaki kanan pasien kusta tipe lepromatosa. Pasien ini seorang penjual buah keliling yang berjalan kaki menggunakan sepatu tertutup, setiap hari. Pada pasien terdapat stocking anesthesia, sehingga tidak menyadari trauma karena gesekan sepatu sehingga timbul bula dan kemudian pecah menjadi luka terbuka.

Ulkus trofik dibagi menjadi beberapa jenis yaitu ulkus akut, ulkus kronik, dan ulkus tanpa komplikasi. ${ }^{5}$ Ulkus akut berupa luka baru pada kulit yang disertai dengan tanda-tanda inflamasi akut. ${ }^{5}$ Ulkus akut menunjukkan gambaran tepi ulkus yang membengkak dan biasanya disertai pus, limfadenitis dan demam, umumnya terjadi leukositosis polimorfonuklear. ${ }^{5}$ Pada ulkus kronik, atau ulkus yang sudah lama terbentuk, tidak terdapat pus, dasar ulkus tampak bersih berupa jaringan granulasi, bentuk punched out atau tepi yang tidak teratur, tidak terdapat sinus dalam, dan tidak terdapat limfadenitis. ${ }^{5}$ Ulkus tanpa komplikasi berupa ulkus yang tidak disertai inflamasi jaringan di sekitarnya (tulang, sendi atau tendon). Pada ulkus ini terdapat banyak pus yang berbau busuk dan sering terdapat jaringan nekrotik. 5 Jenis ulkus pada kasus ini diklasifikasikan sebagai ulkus kronik tanpa komplikasi, karena ulkus telah terjadi selama 4 tahun, dasar ulkus berupa jaringan granulasi, tidak terdapat pus, sinus dan limfadenitis.

Prinsip pengobatan ulkus trofik adalah dengan cara melakukan debridement, memberikan antibiotik jika terdapat tanda-tanda infeksi, mengurangi tekanan mekanik, dan penggunaan dressing. ${ }^{1,5}$ Sampai pertengahan abad ke 20, proses penyembuhan luka yang dianggap terbaik adalah dengan memastikan bahwa luka dalam kondisi kering dan terbuka, dan baru sejak tahun 1960, mulai muncul prinsip penyembuhan luka dengan kondisi lembab. ${ }^{6,9,13}$ Mulai pertengahan tahun 1990-an berbagai jenis modern wound dressing banyak beredar untuk pengobatan luka., ${ }^{9,13}$

Ciri modern wound dressing adalah mampu menjaga kelembaban kulit di sekitar luka, mempercepat migrasi epitel dari jaringan normal ke daerah luka, ${ }^{14}$ merangsang angiongenesis dan sintesis jaringan ikat, menunjukkan pertukaran gas antara luka dan lingkungan luar, menjaga stabilitas temperatur jaringan luka, mengabsorpsi eksudat yang 
berlebihan di sekitar luka, mengeliminasi jaringan mati, dan dapat menghambat pertumbuhan bakteri. ${ }^{6,9,13}$ Pertimbangan lain dalam pemilihan modern wound dressing adalah nontoksik, terjadi pertukaran gas yang baik, kualitas yang baik (tidak mudah robek dan rusak baik pada kondisi basah maupun kering), nyaman, mudah dibersihkan, dan mudah dilepaskan. ${ }^{6,9,13}$ Tidak semua modern wound dressing memiliki keseluruhan sifat ideal tersebut, sehingga kita perlu memilih dressing yang sesuai dengan kondisi pasien. Salah satu jenis modern wound dressing yang sering digunakan adalah hidrokoloid. ${ }^{10}$

Hidrokoloid merupakan adhesive dressing yang dapat berinteraksi langsung dengan cairan di permukaan luka. ${ }^{6,7,9}$ Hidrokoloid merupakan salah satu jenis modern wound dressing yang bekerja secara oklusi. ${ }^{7}$ Pada dressing ini ditambahkan bahan adhesif sebagai perekat dan lapisan absorptif berupa film yang bersifat impermeable terhadap cairan, gas, uap air, dan bakteri. ${ }^{6,9,13,15}$ Hidrokoloid dapat digunakan untuk luka, baik pada kondisi basah maupun kering, karena bersifat dapat menyerap cairan. ${ }^{9,15}$ Indikasi pemakaian hidrokoloid adalah untuk kondisi luka kronis dengan eksudat yang sedikit, luka partial-full thickness, luka dengan dasar jaringan granulasi, luka bakar, luka trauma misalnya abrasi dan laserasi, luka post-operative dan fistula. ${ }^{6,15}$ Kontraindikasi penggunaan hidrokoloid tidak ada, namun lebih baik hidrokoloid tidak digunakan pada luka dengan infeksi dan luka dengan jumlah eksudat yang banyak. ${ }^{6,15}$

Kelebihan hidrokoloid antara lain ukuran dan bentuk dapat disesuaikan dengan luka, memberikan efek lembap, dapat menurunkan $\mathrm{pH}$ di lingkungan sekitar luka, tahan air, impermeable terhadap bakteri, ${ }^{6,9}$ menyerap eksudat (meskipun sedikit), membantu membersihkan luka, memberikan perlindungan dari gesekan, serta tidak menyebabkan nyeri saat dilepas sehingga cocok untuk digunakan pada anak-anak. ${ }^{15}$ Dressing ini ideal untuk debridemen autolitik. ${ }^{9}$ Kekurangan hidrokoloid adalah dapat terjadi dermatitis kontak. ${ }^{13}$ Pada penggunaan hidrokoloid, saat melepaskan dressing sering meninggalkan bahan sisa gel yang menyerupai pus dan bau yang tidak enak, sehingga kadang-kadang dianggap sebagai infeksi. ${ }^{13}$ Pada kasus ini, modern wound dressing yang digunakan adalah hidrokoloid, karena kondisi ulkus dengan eksudat sedikit, dasar ulkus jaringan granulasi, dan tidak terdapat infeksi. Pertimbangan lain adalah ukuran dressing dapat disesuaikan dengan luka dan memberikan perlindungan dari gesekan karena pasien tetap harus bekerja sebagai penjual buah keliling.

Singh dkk. ${ }^{16}$ meneliti perbandingan antara penyembuhan luka kronis yang diterapi dengan hidrokoloid dan kasa konvensional. Berdasarkan hasil penelitian tersebut diketahui bahwa $72 \%$ luka yang diterapi dengan hidrokoloid menunjukan hasil penyembuhan lebih baik dibandingkan dengan kasa. Cuschieri dkk. ${ }^{7}$ melaporkan terapi hidrokoloid pada ulkus kaki nekrotik yang besar pada pasien diabetes. Luka membaik menjadi jaringan granulasi dan mulai terjadi epitelisasi pada pemakaian hidrokoloid selama 10 minggu. Ulkus trofik pada pasien ini mengalami perbaikan pada pengamatan hari ke-28, yaitu ukuran ulkus mengecil dan semakin dangkal. Pemakaian hidrokoloid dihentikan pada pengamatan hari ke-70 karena ulkus telah menutup menjadi sikatriks eutrofi.

Penyakit kusta jarang mengancam kehidupan. Penyebab kematian pada pasien kusta umumnya karena kerusakan ginjal. ${ }^{17}$ Pada pasien ini tidak ditemukan kelainan fungsi ginjal, sehingga quo ad vitam ad bonam. Kerusakan saraf yang menyebabkan deformitas pada pasien kusta bersifat irreversible. ${ }^{18}$ Pada pasien didapatkan gloves and stocking anesthesia dengan kecacatan tingkat 2 berupa ulkus trofik. Meskipun ulkus trofik telah menutup, tetapi meninggalkan sikatriks eutrofi, sehingga quo ad functionam dubia ad malam. Jaringan parut yang terjadi pada ulkus trofik, kemungkinan dapat berulang. ${ }^{5}$ Pada pasien ini terdapat penyembuhan luka berupa jaringan parut. Pasien juga merupakan penjual buah keliling yang setiap hari berkeliling berjualan dengan berjalan kaki, sehingga sulit untuk mengistirahatkan kakinya. Dengan demikian quo ad sanationam dubia ad malam.

\section{SIMPULAN}

Ulkus trofik merupakan salah satu komplikasi yang sering dijumpai pada pasien dengan gangguan neuropati misalnya kusta atau diabetes. Pilihan penanganan ulkus yang tepat tergantung dari kondisi ulkus tersebut. Laporan kasus ini menampilkan ulkus trofik pada pasien kusta yang dapat diterapi dengan dressing hidrokoloid dan menunjukkan hasil penyembuhan yang baik. Berdasarkan laporan kasus ini, penggunaan hidrokoloid merupakan pilihan terapi yang efektif bila digunakan pada jenis luka yang tepat dan dengan pemantauan secara rutin.

\section{DAFTAR PUSTAKA}

1. Puri V, Venkateshwaran N, Khare N. Trophic ulcers-Practical management guidelines. Indian J Plastic Surg. 2012;45:340.

2. Anandan V, Jameela WA, Saraswathy P, Sarankumar S. Platelet rich plasma: efficacy in treating trophic ulcers in leprosy. J Clin Diagnos Research. 2016;10:6-9.

3. Zanchin TN, Serafini CB, Brandão FS, Nery JAC. Polyhexanide $0.2 \%$ in treatment of trophic foot ulcers in leprosy. An Bras Dermatol. 2018;93:145-7

4. Nagaraju U, Sundar PK, Agarwal P, Raju BP, Kumar M. Autologous platelet-rich fibrin matrix in non-healing trophic ulcers in patients with Hansen's disease. J Cutan Aesth Surg. 2017;10(1):3-7.

5. Riyaz N, Sehgal VN. Leprosy: trophic skin ulcers. Skinmed. 2017; 15:45-51.

6. Skórkowska-Telichowska K, Czemplik M, Kulma A, Szopa J. The local treatment and available dressings designed for chronic wounds. JAAD. 2013;68:e117-26.

7. Cuschieri L, Debosz J, Miiller P, Celis M. Autolytic debridement of a large, necrotic, fully occluded foot ulcer using a hydrocolloid dressing in a diabetic patient. Adv Skin Wound Care. 2013;26:300-4.

8. Sweenwy IR, Miraftab M, Colliyer G. A critical review of modern and emerging absorbent dressing used to treat exuding 
wounds. Int Wound J. 2010;9:601-12.

9. Sood A, Granick MS, Tomaselli NL. Wound dressings and comparative effectiveness data. Adv Wound Care (New Rochelle). 2014;3(8):511-29.

10. Jurić Vukelić D, Jurić J. Hydrocolloid dressing application in the treatment of chronic wounds and relation to quality of life. Acta Clin Croat. 2017;56:544-9.

11. Sehgal VN, Prasad PV, Kaviarasan PK, Rajan D. Trophic skin ulceration in leprosy: evaluation of the efficacy of topical phenytoin sodium zinc oxide paste. Int J Dermatol. 2014;53:8738.

12. Fernandes TR, Santos TS, Lopes RR. Leg ulcer in lepromatous leprosy-case report. An Bras Dermatol. 2016;91:673-5.

13. Dhivya S, Padma VV, Santhini E. Wound dressings-a review. BioMedicine. 2015;5(4):24-8.

14. Falanga V, Iwamoto S. Mechanism of wound repair, wound healing, and wound dressing. Dalam: Wolff K, Goldsmith LA, katz SI, Gilchrest BA, Paller AS, Leffell DJ, penyunting. Fitzpatrick's dermatology in general medicine. Edisi ke-8. New York: Mc Graw-Hill; 2012. h. 2984-96.

15. Dabiri G, Damstetter E, Phillips T. Choosing a wound dressing based on common wound characteristics. Adv Wound Care (New Rochelle). 2016;5:32-41.

16. Singh A, Halder S, Chumber S, Misra MC, Sharma LK, Srivastava A, Menon GR. Meta-analysis of randomized controlled trials on hydrocolloid occlusive dressing versus conventional gauze dressing in the healing of chronic wounds. Asian J Surg. 2004;27:326-32.

17. Sanz-Martín N, del Rocío Samillán-Sosa K, De Miguel J, Martínez-Miguel P. Renal amyloidosis in leprosy, an infrequent cause of nephrotic syndrome in Europe. BMJ case reports. 2016;2016:bcr2016216038.

18. Lee D, Thomas H, Rea, Modlin R. Leprosy. Dalam: Wolff K, Goldsmith LA, Katz SI, Gilchrest BA, Leffel DJ, penyunting. Fitzpatrick's dermatology in general medicine. Edisi ke-8. New York: McGraw-Hill; 2012.h.2253-63. 